\title{
Analisis Pelaksanaan Perkuliahan SPH II untuk Buku Ajar Perkembangan Embrio Mamalia
}

\author{
Ulya Ruwaida ${ }^{1}$, Mohamad Amin ${ }^{1}$, Umie Lestari ${ }^{1}$ \\ ${ }^{1}$ Pendidikan Biologi-Universitas Negeri Malang
}

\begin{tabular}{l}
\hline \hline INFO ARTIKEL \\
\hline Riwayat Artikel: \\
Diterima: 10-05-2019 \\
Disetujui: 09-12-2019 \\
\hline
\end{tabular}

\section{Kata kunci:}

textbooks;

mammalian embryo development; conducting lectures;

buku ajar;

perkembangan embrio mamalia; pelaksanaan perkuliahan

\section{ABSTRAK}

Abstract: This study aims to identify the need for the development of SPH II teaching materials on mammalian embryo development material. Data collection research was conducted using student questionnaire sheets. The results of the study show that $100 \%$ of students need the development of new teaching materials with research results that present applicative examples in society. As many as $57 \%$ of students stated difficulties in using available teaching materials because of the complexity of the language and the absence of evaluation. Mammalian embryo development is an elusive material (43\%) and there has never been an explanation of the role of genes in the determination of mammalian twin births. The conclusion of this study is the need for the development of teaching materials in the form of textbooks based on the results of research on the detection and analysis of twin cow marker genes.

\begin{abstract}
Abstrak: Penelitian ini bertujuan untuk mengidentifikasi kebutuhan pengembangan bahan ajar SPH II pada materi perkembangan embrio mamalia. Pengumpulan data penelitian dilakukan dengan menggunakan lembar angket mahasiswa. Hasil penelitian menunjukkan bahwa $100 \%$ mahasiswa membutuhkan pengembangan bahan ajar baru berbasil penelitian yang menyajikan contoh aplikatif dalam masyarakat. Sebanyak 57\% mahasiswa menyatakan kesulitan dalam menggunakan bahan ajar yang tersedia karena kompleksitas bahasa dan belum adanya evaluasi. Perkembangan embrio mammalia merupakan materi yang sulit dipahami $(43 \%)$ dan belum pernah terdapat penjelasan mengenai adanya peran gen dalam penentuan kelahiran kembar mamalia. Kesimpulan penelitian ini adalah perlu adanya pengembangan bahan ajar berupa buku ajar berdasarkan hasil penelitian deteksi dan analisis gen penanda kembar sapi.
\end{abstract}

\section{Alamat Korespondensi:}

Ulya Ruwaida

Pendidikan Biologi

Universitas Negeri Malang

Jalan Semarang 5 Malang

E-mail: uruwaida95@gmail.com

Pendidikan merupakan salah satu alat pengembangan sumber daya manusia dan menjadi hak setiap manusia (Bastian, 2006). Tujuan pendidikan Indonesia yaitu mewujudkan suasana dan proses belajar yang ideal guna mengembangkan kemampuan, watak, serta peradaban bangsa (UU No 20 Tahun 2003). Salah satu upaya pemerintah Indonesia dalam rangka mewujudkan kualitas SDM yang sesuai dengan tujuan pendidikan nasional yaitu dengan mengembangkan kurikulum berbasis Kerangka Kualifikasi Nasional Indonesia (KKNI) yang diterapkan di pendidikan perguruan tinggi. KKNI merupakan perwujudan jati diri dan mutu bangsa dengan mengintegrasikan berbagai bidang pelatihan dalam kegiatannya (Ditjen Dikti, 2010). KKNI sering dirumuskan dalam capaian pembelajaran lulusan yang pada jenjang strata-1 digolongkan dalam level 6, yaitu mampu menerapkan berbagai pemikiran analisis dan aplikatif, membuat desain, pemanfaatan IPTEK, serta dapat memberikan solusi (Kemendikbud, 2014). Capaian pembelajaran lulusan tersebut selanjutnya diturunkan menjadi capaian pembelajaran matakuliah yang dimaksudkan tidak hanya untuk memahami konsep, namun juga menjadi ilmu terapan yang memberikan manfaat praktis.

Struktur perkembangan hewan II merupakan salah satu matakuliah ilmu dasar pengetahuan mengenai perkembangan embrio yang mencakup beberapa pokok bahasan, seperti gametogenesis, fertilisasi, regenerasi, metamorfosis, dan perkembangan embrio hingga menjadi individu baru. Capaian pembelajaran matakuliah ini yaitu mahasiswa diharapkan mampu memahami konsep, prinsip, dan prosedur dalam kajian perkembangan embrio vertebrata sampai menjadi individu baru (RPS SPH II, 2018). Ketuntasan capaian pembelajaran sangat ditentukan oleh penggunaan dan pengembangan bahan ajar dalam kelas yang sesuai dengan karakteristik peserta didik (Primiani, 2014). Salah satu bahan ajar yang sering digunakan pendidik dalam kelas adalah buku ajar. Buku ajar merupakan seperangkat substansi pelajaran yang dikembangkan berdasarkan isi kurikulum yang harus dicapai peserta didik guna menciptakan suasana/lingkungan yang memungkinkan peserta didik untuk belajar (Sihotang dan Sibuea, 2015). Buku ajar juga dapat diartikan sebagai sumber belajar berupa materi pelajaran yang memiliki susunan sistematis dan menampilkan hubungan antarkompetensi yang akan diberikan pada siswa selama proses pembelajaran (Millah et al., 2012). 
Perkembangan embrio mamalia merupakan salah satu materi penting yang terdapat di dalam matakuliah SPH II. Perkembangan embrio mamalia memuat berbagai kajian sub materi seperti fertilisasi, perkembangan embrio pasca fertilisasi, selaput ekstraembrio, dan konsep kelahiran kembar. Berdasarkan wawancara yang dilakukan bersama dosen pengampu matakuliah SPH II ditemukan bahwa ada berbagai kesulitan mahasiswa dalam memahami konsep fertilisasi, perkembangan embrio, dan organogenesis. Selain itu, berdasarkan observasi pembelajaran juga ditemukan bahwa ada banyak materi yang kurang disampaikan dalam presentasi mandiri mahasiswa. Materi tersebut salah satunya adalah adanya peran dan fungsi gen dalam penentuan kelahiran kembar pada perkembangan embrio mammalia setelah fertilisasi.

\section{METODE}

Jenis penelitian ini termasuk dalam penelitian deskriptif kuantitatif. Waktu penelitian dilaksanakan dalam bulan Oktober-November 2018 pada matakuliah SPH II Program Studi S-1 Pendidikan Biologi, Jurusan Biologi, FMIPA, Universitas Negeri Malang. Subjek penelitian ditetapkan secara purposive random sampling dan berjumlah 35 orang mahasiswa. Pengumpulan data dilakukan dengan menggunakan lembar angket yang berisikan 15 pertanyaan pilihan, sekaligus meminta mahasiswa melengkapi dengan alasan untuk setiap jawaban yang dipilih. Tahap penelitian mengikuti tahapan analyze rancangan instruksional ADDIE yang dijabarkan dalam beberapa tahap berikut: (1) analisis permasalahan di kelas, (2) analisis tujuan pengembangan, (3) analisis sasaran pengembangan, (4) mengidentifikasi komponen yang dibutuhkan, (5) menetapkan sistem pengantar, dan (6) menentukan rencana pelaksanaan pengembangan.

\section{HASIL}

\section{Analisis Permasalahan di Kelas}

Tahap ini berfungsi guna mengidentifikasi permasalahan dalam proses pembelajaran matakuliah SPH II materi perkembangan embrio mammalia, khususnya fungsi dan peran gen dalam penentuan kelahiran kembar. Masalah dapat ditemukan dengan membandingkan kondisi di kelas dengan kondisi ideal, serta mengkaji adanya kesenjangan antara kedua kondisi tersebut. Hasil analisis yang dilakukan pada matakuliah SPH II terdiri dapat diketahui melalui tabel 1.

Hasil analisis mengenai kurikulum yang diterapkan pada matakuliah SPH II menunjukkan bahwa telah ada kesinambungan antara CPL dan CPMK yang sudah mampu mengakomodasi tuntutan CP pada KKNI. Hal ini dapat terlihat dari Rancangan Perkuliahan Semester Struktur Perkembangan Hewan II 2018. Berdasarkan hasil analisis juga diketahui bahwa perkuliahan dilakukan sebanyak 16x pertemuan dengan 3x tes tertulis. Matakuliah SPH II mencakup berbagai materi penting yang saling berkesinambungan satu dengan yang lain. Hasil analisis materi menunjukkan bahwa sebagian besar mahasiswa menyatakan bahwa perkembangan embrio mamalia merupakan materi yang sulit dan kompleks. Selain itu, keseluruhan mahasiswa menyatakan bahwa belum pernah ada pembahasan mengenai peran dan fungsi gen kembar dalam proses perkembangan embrio mamalia pasca fertilisasi, meskipun materi tersebut tercantum dalam RPS.

Hasil analisis yang dilakukan terhadap sumber bahan ajar dalam matakuliah SPH II menunjukkan bahwa masih terdapat banyak kesulitan mahasiswa dalam penggunaannya. Kesulitan tersebut, meliputi bahan ajar menggunakan bahasa yang kompleks dan sulit dipahami, belum adanya evaluasi pada bahan ajar yang digunakan. Hasil analisis terhadap buku ajar karya tim dosen pengampu menunjukkan bahwa meskipun penyajian materi telah lebih sederhana, namun masih ada beberapa konsep yang belum disajikan misalnya peran dan fungsi gen yang menentukan kelahiran kembar. Kelahiran kembar dalam buku ajar ini dibahas secara sederhana dan hanya mencantumkan kelahiran kembar hasil partogenesis saja, tanpa adanya pembahasan adanya peran dan fungsi gen penentu kelahiran kembar pada perkembangan embrio mamalia pasca fertilisasi.

\section{Analisis Tujuan Pengembangan}

Analisis tujuan pengembangan merupakan tahap penentuan produk yang akan dikembangkan dalam pembelajaran sesuai dengan hasil identifikasi dan analisis permasalahan. Penentuan produk ditetapkan berdasarkan pertimbangan hasil angket analisis pelaksanaan yang telah diisi oleh mahasiswa. Hasil amnalisis menyatakan bahwa adanya kebutuhan pengembangan produk bahan ajar baru berupa buku referensi/buku ajar yang berbasis penelitian dan sesuai contoh aplikatif masyarakat untuk materi perkembangan embrio mamalia. Harapannya, produk yang telah dikembangkan mampu memberikan pengetahuan hasil penelitian terbaru dan membantu proses pembelajaran matakuliah SPH II, khususnya kelahiran kembar.

\section{Analisis Sasaran Pengembangan}

Sasaran pengembangan penelitian ini yaitu mahasiswa Program Studi S-1 Pendidikan Biologi, Jurusan Biologi, FMIPA, Universitas Negeri Malang yang ditetapkan secara purposive random sampling dan berjumlah 35 orang mahasiswa. 
Tabel 1. Hasil Analisis Pelaksanaan Matakuliah SPH II

\begin{tabular}{lrl}
\hline Capaian Pembelajaran KKNI & \multicolumn{1}{c}{ Capaian Pembelajaran Matakuliah } \\
\hline $\begin{array}{l}\text { Mampu menerapkan berbagai } \\
\text { pemikiran analisis dan aplikatif, }\end{array}$ & 1. $\begin{array}{l}\text { Mahasiswa mampu menguasai konsep, prinsip dan } \\
\text { prosedur dalam kajian perkembangan embrio vertebrata } \\
\text { IPTEK, serta dapat memberikan }\end{array}$ & 2. $\begin{array}{l}\text { Mahasiswa mampu menggunakan konsep, prinsip dan } \\
\text { prosedur dalam kajian perkembangan embrio vertebrata }\end{array}$ \\
solusi & $\begin{array}{l}\text { sampai menjadi individu baru untuk menemukan, } \\
\text { menganalisis dan memecahkan permasalahan dengan } \\
\text { penerapan IPTEK } \\
\text { Mahasiswa mampu menentukan langkah-langkah untuk } \\
\text { memperoleh informasi tentang berbagai permasalahan dan } \\
\text { mengambil keputusan berdasarkan informasi yang akurat } \\
\text { untuk memecahkan permasalahan dalam kajian } \\
\text { perkembangan hewan khususnya terkait lingkungan, dan } \\
\text { kesehatan secara komprehensif } \\
\text { Mahasiswa bertanggung jawab terhadap perencanaan, } \\
\text { pelaksanaan dan evaluasi kerja baik secara mandiri dan } \\
\text { kelompok dalam pengembangan dan pengelolaan bidang } \\
\text { biologi khususnya lingkungan, dan kesehatan }\end{array}$ \\
& 4.
\end{tabular}

Hasil Analisis Perkuliahan \& Proses Pembelajaran

1. $(100 \%)$ menyatakan metode perkuliahan telah sesuai dengan RPS yaitu:

- Ceramah (1\%),

- Diskusi presentasi (43\%),

- Praktikum (46\%),

- Diskusi kooperatif (7\%), dan

- Analisis masalah (3\%)

2. $(57 \%)$ mahasiswa menyatakan suka mengerjakan tugas dengan diberikan soal-soal latihan

3. $(100 \%)$ memanfaatkan teknologi sebagai penunjang media pembelajaran

4. $(100 \%)$ bahan ajar yang digunakan telah sesuai dengan model pembelajaran

5. Bahan ajar yang digunakan dalam pembelajaran, yaitu:

- Buku ajar (28\%),

- Buku elektronik (31\%),

- Petunjuk praktikum (29\%), dan

- Handout (12\%)

6. (43\%) mahasiswa menyatakan kesulitan menggunakan bahan ajar buku ajar dan (57\%) kedulitan dalam menggunakan e-book, karena:

- Bahan ajar menggunakan bahasa yang kompleks (36\%), dan

- Belum adanya evaluasi dalam bahan ajar (64\%)

7. $(100 \%)$ mahasiswa membutuhkan contoh aplikatif kehidupan dalam bahan ajar

8. $(100 \%)$ mahasiswa menyatakan dibutuhkan penambahan dan pembaharuan bahan ajar, yaitu:

- Sumber belajar dari contoh aplikatif di kehidupan (64\%), dan

- Sumber belajar dari penelitian $(36 \%)$

9. $(79 \%)$ mahasiswa menyatakan bahan ajar yang dibutuhkan berupa buku referensi/buku ajar

10. Mahasiswa menyatakan materi pembelajaran yang sulit, yaitu:

- Perkembangan embrio mammalia (43\%),

- Pembentukan dan tipe blastula, gastrula, dan neurulasi (11\%),

- Mekanisme differensiasi (39\%), serta

- Mekanisme terjadinya kembar (7\%)

11. $(100 \%)$ mahasiswa menyatakan belum pernah adanya bahasan peran dan fungsi gen kembar dalam pembelajaran 


\section{Identifikasi Komponen yang Dibutuhkan}

Komponen yang diperlukan dalam penelitian ini yaitu sumber konten, fasilitas pembelajaran, dan sumber daya manusia. Sumber konten diperoleh dari hasil penelitian deteksi dan analisis gen kembar pada sapi, artikel penelitian, dan beberapa buku teks yang terkait materi. Fasilitas pembelajaran, meliputi ruang kelas/ruang laboratorium yang digunakan untuk analisis pelaksanaan dan uji coba produk hasil pengembangan.

\section{Menentukan Sistem Pengantar}

Penentuan sistem pengantar dilakukan guna menganalisis produk yang akan dikembangkan untuk mengatasi masalah yang telah diidentifikasi dalam kelas. Berdasarkan hasil analisis diketahui bahwa sangat diperlukan adanya pembaharuan/pengembangan buku ajar/buku referensi mengenai perkembangan embrio mammalia. Buku ajar diharapkan berasal dari hasil penelitian dan sesuai dengan contoh aplikatif di masyarakat. Perkembangan embrio mammalia dipilih dalam pengembangan buku ajar sebab materi ini memiliki tingkat kesulitan tertinggi dalam keseluruhan materi matakuliah. Buku ajar diantarkan dengan melakukan tatap muka dan memanfaatkan buku ajar yang telah dikembangkan.

\section{PEMBAHASAN}

Pengembangan bahan ajar perlu dilakukan dengan alasan tuntutan pemecahan masalah belajar, kurikulum, dan karakteristik sasaran (Depdiknas, 2008). Pengembangan bahan ajar disesuaikan dengan pembelajaran aktif yang telah dilakukan oleh mahasiswa. Pembelajaran aktif dalam kelas sangat memerlukan berbagai sumber belajar yang berkaitan dengan masalah perkuliahan guna tercapainya capaian pembelajaran (Harsono, 2008). Pengembangan bahan ajar diharapkan juga menyesuaikan dengan perkembangan ilmu pengetahuan, salah satunya memanfaatkan hasil penelitian. Pengembangan bahan ajar berbasis hasil penelitian dinilai dapat menjadi kegiatan yang dapat memperluas dan memperdalam materi secara aplikatif sebagai sumber belajar, serta mampu memberikan pengalaman nyata kepada mahasiswa (Primiani, 2014). Hasil penelitian perlu dijadikan sumber materi pembelajaran di perguruan tinggi sehingga karya peneliti dapat berdaya guna (Parmin dan Peniati, 2012). Bahan ajar yang dikembangkan dengan memanfaatkan hasil penelitian menjadi penting karena materi yang disajikan akan menghubungkan antara fakta yang diperoleh dari pengumpulan data, konsep dan kajian teori, prosedur dan prinsip yang terkandung dalam materi pembelajaran (Parmin dan Peniati, 2012).

Hasil analisis terhadap permasalahan yang telah dilakukan menunjukkan perlu adanya pengembangan bahan ajar tambahan yang memuat materi perkembangan embrio mammalia dengan lebih sederhana dan detail dengan memanfaatkan hasil penelitian terbaru. Berdasarkan hal tersebut, maka bahan ajar yang dipilih untuk dikembangkan adalah buku ajar. Buku ajar yang akan dikembangkan berisikan materi yang disajikan dalam model Problem Based-Learning (PBL) berdasarkan penelitian yang mengintegrasikan riset dalam proses pembelajaran Biologi dengan menggunakan pendekatan molekuler hasil penelitian (Widayati et al., 2010; Hafsah, 2015; Fadli, 2017). Model PBL yang digunakan dalam buku ajar dinilai memiliki keunggulan yakni peserta didik dapat mengembangkan keterampilan untuk belajar seumur hidup dan senantiasa dapat mengembangkan pengetahuan dan kemampuannya (Sumarmi, 2012).

Penelitian yang digunakan sebagai dasar pengembangan buku ajar ini yaitu hasil penelitian deteksi dan analisis gen kembar pada sapi kembar (Bos taurus) menggunakan pendekatan molekuler. Penelitian ini dinilai sangat relevan dalam menjelaskan peran dan fungsi gen penanda kembar dengan materi perkembangan embrio mammalia. Penelitian deteksi dan analisis gen kembar pada sapi menggunakan pendekatan molekuler merupakan salah satu penelitian modern saat ini. Penggunaan penelitian ini dalam buku ajar diharapkan mampu memberikan pandangan nyata kepada mahasiswa mengenai pemanfaatan teknologi terbaru guna kesejahteraan masyarakat sesuai dengan tututan capaian pembelajaran pada matakuliah SPH II (Nasikhawati, 2018). Gen penanda kembar merupakan gen pengendali sifat kelahiran kembar yang dapat meningkatkan frekuensi ovulasi kembar pada satu siklus estrus sehingga kejadian kelahiran kembar juga meningkat (Echternkamp et al., 2007). Gen pengendali kembar pada sapi dapat dikontrol oleh seleksi genetik, pemberian perlakuan hormon, transfer embrio, hormon, dan pakan ternak yang vegetasinya mengandung pytoestrogen (Wakchaure dan Ganguly, 2016; Hosen et al., 2010). Pemahaman peran dan fungsi gen dalam penentuan kelahiran kembar sangat penting disampaikan agar mahasiswa mampu mempertimbangkan adanya potensi betina yang produktif dan tidak produktif. Potensi ini dapat dimanfaatkan untuk menghemat biaya pemeliharaan pakan maupun tenaga pemeliharaan ternak (Inounu, 2017). Pengembangan bahan ajar berupa buku ajar berbasis penelitian ini diharapkan dapat meningkatkan capaian pembelajaran matakuliah SPH II. Pengembangan ini relevan untuk keperluan masyarakat masa depan (Amin, 2015) yaitu pengembangan ekonomi berbasis ilmu pengetahuan dan riset.

\section{SIMPULAN}

Berdasarkan hasil analisis yang telah dilakukan, maka diperoleh kesimpulan bahwa perlu adanya pengembangan buku ajar terbaru yang memuat materi perkembangan embrio mammalia, khusunya peran dan fungsi gen pada kelahiran kembar. Pengembangan buku ajar didukung oleh hasil penelitian deteksi dan analisis gen penanda kembar pada sapi. Buku ajar diharapkan memuat berbagai hasil penelitian terkait materi dan contoh aplikatif di masyarakat sehingga mampu memfasilitasi beberapa permasalahan yang ditemukan dalam pembelajaran SPH II. 


\section{DAFTAR RUJUKAN}

Amin, M. (2015). Biologi sebagai Sumber Belajar untuk Generasi Masa Kini dan Mendatang yang Berintegritas dan Berperadapan Tinggi. Naskah Pidato Pengukuran Guru Besar Universitas Negeri Malang.

Bastian, I. (2006). Akuntansi Pendidikan. Jakarta: Erlangga.

Depdiknas. (2008). Panduan Pengembangan Bahan Ajar. Jakarta: Direktorat Pembinaan Sekolah Menengah Atas.

Ditjen Dikti. (2010). Indonesian Qualification Frame. Jakarta: Depdiknas.

Echternkamp, S. E., Cushman, R. A., Allan, M. F., Thallman, R. M., \& Gregory, K. E. (2007). Effects of Ovulation Rate and Fetal Number on Fertility in Twin-Producing Cattle. Journal of Animal Science, (85), 3228_-3238.

Fadli, R. (2017). Deteksi dan Identifikasi Twinning Rate Gene pada Sapi Kembar Berbasis Mikrosatelit dan Pengembangannya untuk Monograf Genetika tentang Ekspresi Materi Genetik di Perguruan Tinggi. Tesis tidak diterbitkan. Universitas Negeri Malang, Malang.

Hafsah. (2015). Implementasi Riset Based Learning dalam Upaya Peningkatan Kualitas Pembelajaran. Makalah disajikan dalam Seminar Nasional Ekonomi Manajemen dan Akuntansi (SNEMA) Fakultas Ekonomi Universitas Negeri Padang SNEMA.

Harsono. (2008). Student-Centered Learning di Perguruan Tinggi. Jurnal Pendidikan Kedokteran dan Profesi Kesehatan Indonesia, 3(1), 4-8.

Hosen, N., Yanofi, H., \& Nurnayetti. (2010). Identifikasi Sapi Lokal Pesisir Berpotensi Beranak Kembar di Kabupaten Pesisir Selatan Sumatera Barat. Seminar Nasional Teknologi Peternakan dan Veteriner 2010.

Inounu, I. (2017). Dukungan Sains dan Teknologi Reproduksi untuk Mensukseskan Program Sapi Indukan Wajib Bunting. WARTAZOA, 27(1), 23-34.

Kementerian Pendidikan dan Kebudayaan. (2014). Panduan Penyusunan Capaian Pembelajaran Lulusan Program Studi. Jakarta: Direktorat Jenderal Pembelajaran dan Kemahasiswaan Direktorat Jenderal Pendidikan Tinggi Kementerian Pendidikan dan Kebudayaan.

Millah., Budipramana., \& Isnawati. (2012). Pengembangan Buku Ajar Materi Bioteknologi di Kelas XII SMA IPIEMS Surabaya Berorientasi Sains, Teknologi, Lingkungan, dan Masyarakat (SETS). Jurnal BioEdu, 1(1), 19 -24.

Nasikhawati, A. (2018). Deteksi dan Analisis Kandidat Gen Pengendali Kembar Birth Weight Gene Pada Sapi Potong Lokal Jawa Sebagai Pengembangan Buku Referensi Struktur Perkembangan Hewan 2. Tesis tidak diterbitkan. Universitas Negeri Malang, Malang.

Parmin., \& Peniati, E. (2012). Pengembangan Modul Matakuliah Strategi Belajar Mengajar IPA Berbasis Hasil Penelitian Pembelajaran. Jurnal Pendidikan IPA Indonesia, 1(1), 8-15.

Primiani, C. A. (2014). Pengembangan Buku Ajar Berbasis Penelitian Bahan Alam Lokal Sebagai Estogenik pada Matakuliah Fisiologi Hewan. Prosiding Mathematics and Sciences Forum 2014.

Sihotang, C., \& Sibuea, M. A. (2015). Pengembangan Buku Ajar Berbasis Kontekstual dengan Tema "Sehat Itu Penting". Jurnal Teknologi dan Komunikasi dalam Pendidikan, 2(2),169-179.

Sumarmi. (2012). Model-model Pembelajaran Geografi. Yogyakarta: Aditya Media Publishing.

Undang-Undang Republik Indonesia Nomor 20 Tahun 2003 tentang Sistem Pendidikan Nasional.

Wakchaure, R., \& Ganguly, S. (2016). Twinning in Cattle: A Review. ARC Journal of Gynecology and Obstetrics, 1(4), 1-3.

Widayati, D. T., Luknanto, D., Rahayuningsih, E., Sutapa, G., Harsono, Sanayaningsih, R. P., \& Sajarwa. (2010). Pedoman Umum Pembelajaran Berbasis Riset. Yogyakarta: Universitas Gadjah Mada. 